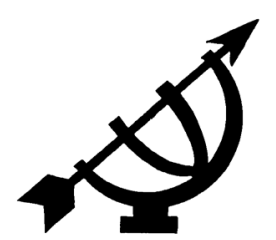

\title{
Education for women: a consideration of the philosophical issues in dialogue with Martha Nussbaum
}

\author{
L.D. Derksen \\ Department of Philosophy \\ Vrije Universiteit \\ AMSTERDAM \\ E-mail: Id.derksen@vu.nl1
}

\begin{abstract}
Education for women: a consideration of the philosophical issues in dialogue with Martha Nussbaum

In some countries in the world, education for women is considered to be unnecessary, undesirable or in conflict with religious principles. Contrary to these points of view, Martha Nussbaum argues that education is important and good. It is one of the capabilities which women need to live a flourishing life.
\end{abstract}

According to Nussbaum, education is a universal value. Pluralists, however, are of the opinion that considering education to be a universal value, in fact, constitutes the imposition of a western value on other cultures. They consider this to be wrong. Nussbaum agrees with this, arguing that we should respect other cultures and that it is not her aim to impose values on them.

In this article, I will investigate how Nussbaum seeks to reconcile her universalism (education as universal value) with the pluralist respect for the choices made in other cultures. I begin by describing Nussbaum's view of education as a capability. I then discuss three examples of arguments through which Nuss-

1 In her work in South Africa and in Canada and in her functions as Professor of Philosophy and Head of the Philosophy Department at Potchefstroom University and as Vice-President of Redeemer College, Elaine Botha has contributed greatly to Christian higher education. Equally important, she is in all respect a wonderful person. I am, therefore, honoured to be able to write an article for this festive edition of Koers which seeks to celebrate Elaine Botha's work. 
baum attempts to close the gap between universalism and pluralism as well as her notions of context and practical judgement.

In conclusion, I argue that although Nussbaum has made a significant contribution to the universalism-pluralism debate, these two positions have not been completely reconciled.

\section{Opsomming}

\section{Opvoeding vir vroue: 'n besinning oor die filosofiese kwessies in gesprek met Martha Nussbaum}

Die opvoeding van vroue word in sommige lande as onnodig beskou, onwenslik of in stryd met godsdienstige beginsels. Hierteenoor argumenteer Martha Nussbaum dat opvoeding 'n belangrike en goeie waarde op sigself is. Dit is een van die bekwaamhede wat vroue benodig om 'n vervulde lewe te lei.

Volgens Nussbaum is opvoeding 'n universele waarde. Daarteenoor betoog sommige pluraliste dat die beskouing van opvoeding as universele waarde in werklikheid neerkom op die afdwinging van 'n westerse kulturele waarde op ander kulture. Volgens hulle mag dit nie gebeur nie. Nussbaum is dit hiermee eens en betoog dat ander kulture gerespekteer behoort te word en dat dit nie haar bedoeling is om waardes op hulle af te dwing nie. In hierdie artikel toon ek aan hoe Nussbaum probeer om haar universalisme (opvoeding as universele waarde) te versoen met die pluralistiese respek vir die keuses wat in ander kulture gemaak word. Eers word Nussbaum se siening van opvoeding as bekwaamheid ("capability") beskryf. Daarna kom drie argumente aan die beurt aan die hand waarvan Nussbaum die kloof tussen universalisme en pluralisme, sowel as haar opvattings oor konteks en praktiese oordeel, probeer oorbrug.

Ten slotte word argumenteer dat Nussbaum 'n betekenisvolle bydrae tot die universalisme-pluralisme debat gelewer het, maar dat hierdie twee posisies nogtans nie heeltemal versoen is nie.

\section{Introduction}

Education for women is, even in the West, a relatively recent phenomenon. It is only at the end of the nineteenth century that European women were allowed to attend universities. For the general population, however, higher education for women is even more recent. Women who are only slightly older than myself tell of a youth in The Netherlands in which the parents decreed that the boys should have higher education and the girls quit school at a young age or attend a domestic science school. Today, in many countries in the world, wo- 
men are still deprived of the right to education. This can be because of poverty, ignorance, social conventions, sexism, or religious convictions. Literacy statistics give an indication of how widespread the exclusion of women from education is. The ratio of literacy of women to men is, for example 35\% in Nepal, $37 \%$ in Sierra Leone, $27 \%$ in Sudan, $32 \%$ in Afghanistan and $50 \%$ in South Asia. Two thirds of illiterate people in the world are women. In higher education, the gap between men and women is even greater (Nussbaum, 1999:31). In western countries, especially those with a large immigrant population, there is also a gap between literacy rates of men and women.

Many people are of the opinion that women in all countries of the world should have access to education. In this article, I will call this the universalist position. There are others - philosophers, anthropologists and economists - who argue that, because there is strong resistance to the education of women in some cultures, education for women should not be imposed on those cultures. This would constitute the imposition on them of western values. I will call this the pluralist position.

In various publications, Martha Nussbaum describes the discussion between the universalist and the pluralist positions as it took place within WIDER (World Institute for Development Economics Research), a think-tank set up and sponsored by the United Nations (Nussbaum, 1998:766-784; 1999:35-37). Nussbaum criticises a certain form of pluralism, stating:

Under the banner of their fashionable opposition to universalism march ancient religious taboos, the luxury of the pampered husband, educational deprivation, unequal health care, and premature death. (Nussbaum, 1999:36.)

Educational deprivation for women is, according to Nussbaum, one of the results of not seeing education as a value to be universally implemented.

The fact that Nussbaum supports the education of women does not, however, mean that she has a rigid universalist position or that she completely rejects pluralism. Her aim is to create a philosophical view in which she does justice to what she considers to be the legitimate claims of both. In this article, I would like to give several examples of how Nussbaum seeks to close the gap between universalism and pluralism with respect to the education of women and I will ask to what extent she succeeds in doing so. 
I will begin by showing that Nussbaum believes education for women to be a great good. It is, according to her, one of the fundamental capabilities needed for women to live a flourishing life. I will then discuss three arguments which Nussbaum uses to close the gap between a universalist and a pluralist position, namely arguments concerning the identification of a culture, group or tradition, her discussion concerning the notion of preferences and her view on freedom of religion. I will also suggest that two concepts which Nussbaum introduces can be valuable for closing the gap which inevitably remains between pluralism and universalism, namely that of context and that of practical judgement.

\section{Education for women as a specific good}

Nussbaum includes education in her list of capabilities. Capabilities are goods which all people are entitled to. Capabilities enable people to lead flourishing lives. The capabilities concern fundamental matters such as being able to live a human life to its normal length, having access to medical care, nourishment and shelter. However, being able to live a truly human life also includes capabilities such as being able to have attachments, having a normal emotional development, and being able to plan one's life by the use of practical reason. There are also elements taken up in the capabilities list which have the character of rights, namely the right of free affiliation, protection against discrimination, the right to work, being able to participate in the political process and being able to hold property.

Nussbaum (1999:78-79) describes the capability concerning education as follows.

Being able to use the senses, to imagine, think, and reason and to do these things in a 'truly human' way, a way informed and cultivated by adequate education, including, but by no means limited to, literacy and basic mathematical and scientific training.

Besides this specific reference to education, education is implied in a number of other capabilities - for example being able to express oneself artistically, having freedom of expression, being able to participate in the political process, and being able to work and seek employment on an equal basis with others (Nussbaum, 1999:78-80). Nussbaum notes that her capabilities are intertwined - that the capabilities form a whole and that the loss of certain capabilities entails the loss of other capabilities. 
The basis for formulating the capabilities lies in the philosophies of Aristotle and Kant. From Aristotle, Nussbaum takes the notion that specific values must be realised for people to flourish. In addition, Aristotle believes that these values apply to all people and are therefore universal. Nussbaum (1999:38) quotes Aristotle by saying:

One may observe in one's travels to distant countries the feelings of recognition and affiliation that link every human being to every other human being.

From Kant, she takes the notion that people have dignity and worth, that they are ends in themselves and not means to other ends (Nussbaum, 2000:73). She regards the capabilities as realisations of these Kantian values. Finally, Nussbaum (2000:150-151) speaks of an intuitive notion of the good when she states:

[T] he capabilities view embodies an intuitively powerful idea of truly human functioning that has deep roots in many different traditions. I have used this intuitive idea to justify the list and its political role.

Not all philosophers agree with Nussbaum that making a list of capabilities is a wise strategy for creating a view of society which encourages flourishing. Sen, for example believes that the best strategy to achieve such a goal is to develop indexes which make clear what specific groups of people, in concrete circumstances, in a specific country, are capable of being and doing. The GNP (gross national product) is an inadequate measure of capability, because a country can have a large GNP and at the same time have a great number of people who live in poverty, unable to realise a minimal standard of living. Examples of indexes which are more precise in this respect are the Human Development Index, the Gender-Disparity Adjusted HDI, the Gender-Related Development Index and the Gender Empowerment Measure (Nussbaum, 1998:782-783). This is a much broader and more abstract notion of capability than Nussbaum (1999:12) has.

Nussbaum argues that the list of capabilities is based on the general theoretical principle that there are universal values which must be realised for all people to have a truly human existence. However, contrary to Sen, Nussbaum sees no reason why the philosopher should limit him-/herself to abstract principles and not formulate specific values. This concreteness encourages the setting of specific goals to be realised. According to Nussbaum, setting specific goals does not imply imposing these goals on people, because the capabilities are opportunities to be realised and not prescriptions (Nuss- 
baum, 2000:105). They are therefore responsive to public reasoning. Actual functioning is a matter which people must decide for themselves. Furthermore, she argues in response to Sen that all the elements in her list are equally important and exist in interplay with each other. It is not an issue of making priorities or a selection as he suggests. Finally, she states that the list is tentative and open to revision. In this sense, it could be more or less specific.

It has been argued that by making a list, one has already made choices for people, choices which they themselves should be able to make. Nelson (2008:115) states that

Neither primary goods [Rawls] nor 'central capabilities' [Nussbaum] are things we all want no matter what else we want; the act of making a list is therefore inherently sectarian.

By this he implies that any formulation of concrete goals by philosophers will stand in the way of the freedom of a democratic, liberal society to make its own choices as to which values to implement (Nelson, 2008:115). To this Nussbaum responds that she respects the choices made by a liberal, democratic society. This respect for freedom of choice is moreover based on her conviction that the power of moral choice is one of the constituents of human dignity (Nussbaum, 1999:57).

\section{The tension between universalism and pluralism}

Nussbaum argues that it is possible for the philosopher to formulate specific capabilities and that one such capability is the right to education. At the same time, Nussbaum describes education as a universal value. By this Nussbaum means that if something is seen as good it should be considered to be universally applicable. Something which is good, is good for all people at all times. This is because, as Aristotle says in the quotation given above, we all share in the same human condition.

At the same time, as we have just seen, Nussbaum claims to do justice to pluralism, stating that she respects the choices made by a liberal, democratic society. In such a society, goods are realised with the consent of society itself. Nussbaum argues that it is possible to subscribe to certain values and consider them universal goods while at the same time respecting cultural differences and the freedom of people to make their own decisions. Nussbaum (1999:8) writes in Sex and social justice: 
These essays ... try to show that a universal account of human justice need not be insensitive to the variety of traditions or a mere projection of narrow Western values onto groups with different concerns.

In her book Women and human development, Nussbaum (2000: 105) speaks of "legitimate worries about universalism", that is worries that universalism can lead to tyranny and of our desire to alleviate these worries.

Nussbaum attempts to reduce the tension between universalism and pluralism by investigating the presuppositions of these points of view. I will illustrate this by giving three examples of how Nussbaum wishes to achieve this. The first example is the issue of how to identify a culture, group, tradition or religion.

\section{Identifying a culture, group, tradition or religion}

Pluralism seeks to respect the opinions of specific religions, traditions, groups or cultures. It is, however, very difficult to identify these social entities. To go back to the earlier example, the Dutch parents who denied their daughters an education 60 years ago could be seen to form a group in society. However, there was also a group of parents who were open to education for their daughters. Which of these two groups represented Dutch culture at that time? Or, did both groups form part of a culture which was itself divided? If we have trouble identifying our own traditions, this is all the more so in the case of traditions and cultures which are foreign to us. Do the Taliban in Afghanistan represent the view of that culture on the education of women or are the true representatives of Afghan culture those people who send their daughters to school?

Nussbaum argues that there is a general tendency in the West to interpret other cultures in terms of its most repressive elements. This is all the more so the case when it involves a description of a Third World culture from a colonialist perspective. She gives the example of the British interpretation of the culture of India. The colonialists decreed that Indian culture was backward, contrasting it to the socalled enlightened British culture. Nussbaum (2000:47) writes:

The British in India harped continually on elements of Indian culture that they could easily portray as retrograde; they sought to identify these as 'Indian culture', and critical values (especially those favoring women's progress) as British importations. 
The point which Nussbaum makes can also be made for religions. In the media, one sees a tendency to interpret Islam in its most repressive forms, especially when it comes to its treatment of women. Should there not be more attention paid to enlightened schools of thought in Islam? Nussbaum notes that also in the case of Hinduism in India, it is possible to focus on repressive or on enlightened forms. Some forms of Hindu law in India, for example mandate polygamy and forbid divorce while "one recognised system of Hindu law already mandated monogamy and gave women divorce rights".

Nussbaum asks what a "typical" group is within a culture containing an "average" person. How do we select which groups we focus on when it comes to women's liberation? Do we choose a group opposed to the emancipation of women? Or do we take as typical of a culture a group of women who work in a collective set up by an aid agency? Or women who make use of microcredit to set up businesses? Or is the group we choose to see as exemplary one of welleducated feminists working for the emancipation of women in their culture?

Nussbaum (1999:9) at one point asks:

What is East and what is West? What is the tradition of a person who is fighting for freedom and empowerment? Why should one's group be assumed to be the ethnic or religious group of one's birth? Might it not, if one so chooses, be, or become, the international group of women - or of people who respect the equality and dignity of women?

Nussbaum, as a representative of United Nations development projects, met with groups of women participating in projects focused on emancipation. This is the reason why she mentions those groups. One can ask how typical such groups are of the culture - on what basis do we make a selection? In her writing, Nussbaum herself makes selections. She makes use of a narrative method in which she takes specific stories of Third World women she met as illustrations of her theories. In Women and human development (Nussbaum, 2000), she tells the stories of Vasanti and Jayamma. By weaving her philosophy around these stories, Nussbaum selects the women she sees as illustrative of the philosophical points she wishes to make (Jaggar, 2006:306, 320). Once more, the difficult issue of selection arises. It can be argued that if one is claiming that all voices in a tradition or culture should be heard, then this applies to both the traditional and the emancipatory elements in the culture. 
Nussbaum also discusses the concept of tradition. She argues that, because cultures change, we cannot impose a rigid notion of tradition on cultures. Nussbaum (1999:37) states:

\begin{abstract}
Real cultures contain plurality and conflict, tradition, and subversion. They borrow good things from wherever they find them, none too worried about purity. We would never tolerate a claim that women in our own society must embrace traditions that arose thousands of years ago - indeed we are proud that we have no such traditions. Isn't it condescending then, to treat Indian and Chinese women as bound by the past in ways that we are not?
\end{abstract}

Nusbaum argues that it is not easy to identify a culture, tradition, group or religion. These social formations are divided and in continuous change. They contain both traditional and non-traditional elements. Nussbaum attempts to diminish the gap between universalism and pluralism by pointing to the fact that identifying these social entities is a matter of interpretation. Furthermore, by focusing on the elements which are more in line with the universalist project she seeks to diminish the appeal of pluralists to traditional elements as representative of a culture. This is, I think, a wise strategy. The question can, however, be asked if Nussbaum succeeds in closing the gap between universalism and pluralism. The universalist and the pluralist can on this reading continue making interpretive choices which emphasise their differences.

\title{
5. The role of preferences
}

A second way in which Nussbaum attempts to diminish the gap between universalism and pluralism is by means of an examination of the notion of preferences. Pluralism seems to be committed to take preferences as normative, universalism seems to ignore them by imposing values on people.

In her book Women and human development, Nussbaum (2000: 111-166) discusses preference in the light of preference-based theories as they have been developed in the field of economics. In economics, the question can be asked whether a society should reflect and respect the preferences of people or not. If people have a preference for a massive consumption of goods should economics and society enable them to exercise this preference, or are there other goals which a society should strive for, for example the just distribution of wealth or concern for the environment? These goals could be at odds with the preferences of people within a society. 
In preference-based theories of economics, it is argued that economics should strive to realise what people want. Opponents to preference-based theories argue that economics should not simply be based on preferences since preferences can be deformed or uninformed (Nussbaum, 2000:119-135). Massive consumption of goods, for example, could prove to be a deformed and uninformed preference.

Applying the notion of preferences to the capabilities, Nussbaum believes that not wanting to realise certain capabilities, such as education, comes from having deformed or uninformed preferences. She argues that one can identify a preference as deformed when it is formed under duress. It can be uninformed if one is simply unaware of what a great good the alternative in fact is. Nussbaum supports her view that preferences can be deformed or uninformed by pointing out what happens when a capability which people at first did not prefer, is realised in a society. Nussbaum claims that once people have access to clean water, medical care, or education they will not want to go back to the situation in which they did not have these things. With respect to education, Nussbaum speaks of the joy which people experience when they become literate. In addition, education opens up all sorts of opportunities which people in the past did not have, not the least of which is the opportunity for employment and the development of a country.

Granting Nussbaum the point that some preferences are better than others, it is nevertheless possible to ask if one can speak of a clear distinction between informed preferences on the one hand and uninformed or deformed preferences on the other. Perhaps some preferences fall in a category between informed and uninformed, or perhaps our judgement as to what is informed and uninformed changes in the course of time. The notion of preference is, therefore, subject to interpretation within a culture.

Because of her respect for a liberal and democratic society, Nussbaum speaks of the importance of respecting the preferences of people. However, at the same time she believes in the "substantive good". By the substantive good Nussbaum refers to a Platonic notion of the good - something which is simply good, regardless of the fact of whether or not people recognise it as good. She concludes her discussion of preference-based theories versus a theory based on the notion of the substantive good with a clear statement in favour of the substantive good. 
While not dismissing desire, as I have said, while keeping it around as a witness and respecting it as an intelligent part of the human personality - we had better take our stand squarely in the camp of the substantive good. (Nussbaum, 2000:166.)

The idea that there is a substantive good, regardless of whether or not people prefer this good, may seem to tip the scales of Nussbaum's position towards the universalist side. Moreover, the substantive good, that which is good for you, seems to lend itself to being imposed on people. Nussbaum, however, argues that it is not simply a question of the imposition of a good. Rather, in order for goods to be implemented, people will need to recognise the value of these goods. Therefore, even though she takes her stand in the camp of the substantive good, this is not a good which is completely cut off from preferences.

By arguing that society need not respect all preferences on the ground that not all preferences are informed and good for people, Nussbaum questions an important presupposition of the pluralist position. At the same time, by arguing that the substantive good needs affirmation through the preferences of people, she questions the idea that a universalist position consists of the mere imposition of values. The pluralist is forced to admit that there can be good things which are to some extent separate from preferences and the universalist must admit that people need to affirm the substantive good. In this way, another step is taken in closing the gap between universalism and pluralism. At the same time, the gap is not completely closed, because when difficult decisions have to be made, the pluralist may perhaps choose a preference-based good while the universalist will choose for imposition of a value.

\section{Freedom of religion}

A last example which I would like to give of the way in which Nussbaum attempts to close the gap between a pluralist and a universalist position regards religion. Respect for freedom of religion is often used by pluralists as an argument against the introduction of certain new values. Some religious groups argue that women should not be educated, because the religion forbids it. The best known example today is that of the Taliban in Afghanistan, but the opposition of religious groups to the education of women is much more widespread. Nussbaum (1999:30) gives the example of Bangladeshi women who were threatened by religious leaders with breaking their legs if they went to literacy classes. However abhorrent this example may be, it confronts us with the issue of respect for freedom of 
religion. Nussbaum (2000:167-240; 2008) considers this question of utmost importance, discussing it at length in various publications.

Religion can form a significant barrier to the acceptance of equality for women. According to Charlesworth, the ratification process of the United Nations' Convention on the Elimination of All Forms of Discrimination against Women of 1979, also known as the Women's Convention, demonstrates that states use religion as a reason for not agreeing to the principle of equal rights for women. Charlesworth (2000:67) writes:

Islamic states are still considered parties to the Women's Convention although they have rejected the equality provisions that are at its heart.

Surprisingly, however, Charlesworth (2000:67) continues:

Israel, India and the United Kingdom have entered reservations making the laws of religious communities immune to the conventions' guarantee of sex equality. Other states, such as Australia, have not formally made reservations precluding the application of the principle of sex equality to religious communities, but they have exempted religions from the principle in legislation designed to implement the Women's Convention.

This shows that religion can be used as a motive for rejecting equal rights for women. This is not only the case in non-western countries, but in a number of western countries as well.

Nussbaum recognises that religion is a powerful influence and that it can be used to block the implementation of what she considers to be important values in a society. At the same time, she believes strongly in respect for religious freedom. She has written extensively on this topic, dedicating a book called Liberty of conscience (Nussbaum, 2008) to this issue in the United States. While arguing for capabilities and universal values on the one hand, Nussbaum argues that, on the other hand, religion does have a certain privileged status in society and that one cannot simply impose values on religions. Central to her notions concerning freedom of religion are the principles of non-establishment and free exercise (Nussbaum, 2000:189). Non-establishment refers to the fact that in the United States there is no "established", that is official, religion. Free exercise means that people are in principle free to exercise their religion.

Examples of her discussions of freedom of religion in the United States are issues concerning the right of the Roman Catholic 
Church to ban women from priestly office, the right of some Mormon sects to practice polygamy, the right of Seventh Day Adventists to claim Saturday as a day free from work, and the right to use drugs in certain religious rituals (Nussbaum, 2000:167-240). Nussbaum argues that the state should respect religious convictions as long as these practices do not harm society as a whole. She calls this the principle of moral constraint (Nussbaum, 2000:190). At the same time, Nussbaum (2000:198) believes that "compelling state interests" must not be undermined by religious practices. Allowing the peyote ceremony in North American Indian religious rituals, for example does not constitute a legal basis for social tolerance for drug use outside of this religious practice (Nussbaum, 2000:208). This means that there are no moral constraints or compelling state interests to forbid such a ceremony. These principles, however, are difficult to apply and as Nussbaum demonstrates, different American courts have made different decisions throughout time in the cases she discusses.

In Women and human development, Nussbaum discusses one particular case which concerns the relation between religious conviction and the right to education. This is the case of Wisconsin v. Yoder before the courts in the United States in which the Amish argued that they would like to take their children from school at the age of fourteen, thus denying them secondary education. The Amish argued that their religious tradition demanded that they withdraw their children from the secular world at this age, teaching them skills of farming and domestic labour (Nussbaum, 2000:232-233). The Supreme Court ruled that the law mandating education until the age of sixteen posed a "substantial burden" for the free exercise of the religious convictions of the Amish and that the state had failed to show that there was a compelling interest to mandate education until the age of sixteen. It was noted by the Supreme Court that the educational system should ensure that children be made into self reliant citizens and able to participate in the political process. However, in the case of the Amish, it had been demonstrated that they do not "place burdens on society through their educational shortcomings" (Nussbaum, 2000:233).

Nussbaum agrees in principle with the Supreme Court's decision, yet at the same time she expresses a number of reservations. Firstly, she states that there is "an element of tragedy" in this decision. Young people loose the right to education, because of respect for freedom of religion (Nussbaum, 2000:212). Secondly, she returns to a point made earlier, that religions can change in the course of time 
(Nussbaum, 2000:212). Thirdly, she notes that the difficulty here is "a use of judgment in its application to the particular" and that "an irreducible element of judgment remains" (Nussbaum, 2000:212). I will return to this notion of judgement in the next section of this article, because I think it is an important idea.

It is clear from these observations that Nussbaum deplores this decision on the one hand and that, on the other hand, she wishes to respect freedom of religion if there is no compelling interest to violate that freedom. Taking up this discussion later in her book, Nussbaum (2000:233) notes:

This is truly a hard case for my approach; indeed, it shows exactly where the line drawn by my approach falls.

At this point, she makes a fourth observation, that while boys will learn skills such as farming and carpentry which they can use everywhere, girls learn to perform domestic tasks, skills which are not very valuable if they choose to leave the Amish community. She, therefore, concludes that if the court had considered the question of the gender of the children, an argument could be made that there really is a compelling interest to forbid taking the children from school (Nussbaum, 2000:233).

I have gone into the discussion of the right of the Amish to deny their children secondary education at length in order to illustrate how difficult it is, even in a modern society such as that of the United States, to reconcile the right to education with the right to the free exercise of religion. In addition, women's rights make this issue all the more complicated.

From this discussion, we can see that Nussbaum rejects both an extreme pluralist position and an extreme universalist position. She argues that religious freedom is not absolute. At the same time, the universalist cannot impose values on religious communities at will. Yet, a gap remains between the pluralist and the universalist. This gap can lead to tragic decisions being made in which interests of equal value are weighed against each other.

Nussbaum seeks to close the gap by arguing that religions evolve, presumably to positions which are more in line with the universalist approach. Yet, precisely in this point there lies a great difficulty. Some religions evolve to more fundamentalist forms, with the result that the differences with liberalism become greater, not less. Fun- 
damentalists are usually not open to compromise with the universalist or to the interference of the state with their convictions.

Another way of closing the gap, but one which Nussbaum does not consider, would be through changes in the universalist position. The universalist position could in theory alter in response to religious impulses. However, the gap could also widen because of changes in the universalist position. It could also be possible for the universalist position to take on forms which take it further from a pluralist position.

\section{Context and practical judgement}

Nussbaum presents a number of arguments by means of which she wishes to close the gap between a pluralist and a universalist position. As I have shown, however, these arguments cannot completely bridge these two positions. I would, therefore, like to introduce two additional notions which may be helpful in closing the gap further, namely those of context and of practical judgement.

Nussbaum argues that education should take place within the context of the society in which it is offered. In Sex and social justice, she gives the example of Martha Chen's literacy project in Bangladesh. Once the female students were literate, the women were given work in "... jobs that looked continuous with traditional female work but were outside the home and brought in wages" (Nussbaum, 1999: 51). Nussbaum (1999:51-52) notes further that the women convinced the men that the changes were not threatening and were good for the whole group. Nussbaum does not endorse this strategy as ideal, noting that it does not solve the problem of the subordination of women. Yet, the introduction of literacy education and the resulting changes in role divisions between men and women are here placed within the context of the lives of the people in the Bangladeshi village. Along the same lines, it could be argued that the content of the education being offered should be within the context of the cultures within which it takes place.

The notion of context is an important one if one wishes to close the gap between pluralism and universalism. Universal values can be introduced into local contexts and can even be modified by those contexts. At the same time, the values can alter the contexts. Once literacy has been introduced into a society, the circumstances under which people live change. It is possible that a small change such as literacy has radical implications in the long run. 
At the same time, the notion of context raises the issue of interpretation once again. Which context should be taken as normative? Do all contexts have an equal claim to legitimacy? Nussbaum wonders whether it is good to compromise when it comes to the subordination of women just to ensure that the greater good, the educational project, can continue.

A second notion which may be helpful to close the gap between universalism and pluralism is that of "judgment in application to the particular", an expression Nussbaum uses in her discussion of freedom of religion. Reconciling the claims to universal values with the right of people to make their own choices, is a matter of carefully weighing options. This weighing of options is a matter of using practical reason. The fact that people must make concrete decisions in practice may lessen the theoretical gap between universalism and pluralism. However, this appeal to practice leaves unanswered the question of principle - the grounds on which the practical decisions are based.

\section{Conclusion}

I have considered two opinions concerning education for women, namely that it is a universal good which must be implemented everywhere, and that it is a western value which should not be implemented if a culture opposes it. I have called these positions universalist and pluralist. In this article, I have given examples of how Nussbaum wishes to close the gap between these positions, taking as point of departure her claim that universalism need not be insensitive to pluralist concerns. I discussed her arguments for this position as well as her notions of context and practical judgement.

I have argued that, although Nussbaum has succeeded to some extent to close the gap, the gap remains. At a certain point, difficult choices have to be made, choices in which either the pluralist position or the universalist position will prevail. Nussbaum (1999:49) clearly states that if it comes to that point, especially when it comes to education, she will choose the universalist side. This is the side of the "substantive good". The very fact that Nussbaum feels she has to make a choice for this pole means that, despite her attempts to resolve the issues, she realises that a complete reconciliation of pluralism with universalism may not be possible. In this article I have tried to point out some of the reasons why this is the case. 


\section{List of references}

CHARLESWORTH, H. 2000. Martha Nussbaum's feminist internationalism. Ethics, 111:64-78.

JAGGAR, A.M. 2006. Reasoning about well-being: Nussbaum's methods of justifying the capabilities. The journal of political philosophy, 14(3):301322.

NELSON, E. 2008. From primary goods to capabilities: distributive justice and the problem of neutrality. Political theory, 36:93-122.

NUSSBAUM, M.C. 1998. Public philosophy and international feminism. Ethics, 108:762-796.

NUSSBAUM, M.C. 1999. Sex and social justice. Oxford: Oxford University Press.

NUSSBAUM, M.C. 2000. Women and human development: the capabilities approach. Cambridge: Cambridge University Press.

NUSSBAUM, M.C. 2008. Liberty of conscience: in defense of America's tradition of religious equality. New York: Basic Books.

\section{Key concepts:}

education for women

freedom of religion

Nussbaum, Martha

universalism and pluralism

\section{Kernbegrippe:}

godsdiensvryheid

Nussbaum, Martha

opvoeding vir vroue

universalisme en pluralisme 
